кова, И.И. Русакова, В.А. Железникова, Т.П. Градобоева // Российская сельскохозяйственная наука. - 2017. - № 6. - С. 3-6.

4. Сортовое районирование сельскохозяйственных культур по Новосибирской области на 2019 год / Филиал ФГБУ «Госсорткомиссия» по Новосибирской области Минист.сельск. хоз. РФ. Новосибирск. 2019. 148 с.

5. Лоскутов И.Г., Ковалева О.Н., Блинова Е.В. Методические указания по изучению и сохранению мировой коллекции ячменя и овса. СПб.: ГНУ ВИР Россельхозакадемии, 2012. $63 \mathrm{c}$.

6. Доспехов Б.А. Методика полевого опыта (с основами статистической обработки результатов исследований) Б.А. Доспехов. - 6-е изд., стер. - М.: ИД Альянс, 2011. $-352 \mathrm{c}$.

DOI 10.18699/GPB2020-111

\title{
Молекулярно-генетическая характеристика образцов озимой мягкой пшеницы в связи с селекцией на устойчивость к полеганию
}

Сычева Е.А. ${ }^{\text {I* }}$ Бондаревич Е.Б. ${ }^{\text {, }}$ Соловей Л.А. ${ }^{1}$, Шимко В.Е. ${ }^{1}$, Гордей С.И. ${ }^{2}$, Дубовеи Н.И. ${ }^{l}$

${ }^{1}$ Институт генетики и цитологии Национальной академии наук Беларуси, 2. Минск, Республика Беларусь;

${ }^{2}$ Научно-практический центр НАН Беларуси по земледелию, г. Жодино, Республика Беларусь.

*e-mail: E.Sycheva@igc.by

Изучены кариотипы и аллельное состояние генов короткостебельности Rht-B1, Rht-D1 и Rht8 y 32 сортов и селекционных образиов озимой мягкой пшеницьл. Установлено, что 6 образиов содержат в кариотипе транслокачию $1 R S .1 B L$, у 4 образиов выявлена делеция 5BS.5BL-del. B проанализированном селекиионном материале преобладали (37,5\%) растения с генотипом Rht-Bla, Rht-D1a, Rht8b. В 18,8\% случаев присутствовал генотип Rht-B1b, Rht-Dla, Rht8b, с одинаковой частотой 9,4\% встречались геноmuпbl Rht-Bla, Rht-Dla, Rht8a / Rht-Bla, Rht-Dlb, Rht8a / Rht-Bla, Rht-Dlb, Rht8b. Генотипь Rht-B1a, Rht-Dla, Rht8c и Rht-B1a, Rht-D1b, Rht8j выявлень y $6,3 \%$ образиов.

Ключевые слова: озимая мягкая пшеница, устойчивость к полеганию, ДНК-маркеры, кариотип, С-бэндинг.

\section{Molecular Genetic Characteristics of Winter Wheat Varieties and Lines in Connection with Breeding for Lodging Resistance}

SychevaE.A. ${ }^{l}$, Bondarevich E.B. ${ }^{l}$, Solovey L.A. ${ }^{l}$, Shimko B.E. ${ }^{l}$, Gordey S.I. ${ }^{2}$, Dubovets N.I. ${ }^{1}$ 
${ }^{1}$ Institute of Genetics and Cytology of the National Academy of Sciences of Belarus, Minsk, Republic of Belarus; ${ }^{2}$ Scientific and Practical Centre for Arable Farming, Zhodino, Republic of Belarus.

The karyotypes and allelic status of Rht-B1, Rht-Dland Rht8 genes were studied in 32 winter wheat varieties and breeding lines. It was found that 6 samples contain the $1 R S .1 B L$ translocation in the karyotype and $5 B S .5 B L$-del deletion was identified in $4 \mathrm{f}$ samples. Plants with the Rht-Bla, Rht-Dla and Rht8b genotype predominated in the analyzed breeding material (37.5\%). In $18.8 \%$ of cases, the Rht-B1b, Rht-Dla and Rht8b genotype was present. With the same frequency of $9.4 \%$, Rht-Bla, Rht-Dla, Rht8a / Rht-Bla, Rht-Dlb, Rht8a / Rht-Bla, RhtDlb, Rht8b genotypes were observed. Rht-Bla, Rht-Dla, Rht8c and Rht-Bla, Rht$D 1 b, R h t 8 j$ genotypes were detected in $6.3 \%$ of samples. banding.

Key words: winter wheat, lodging resistance, DNA markers, karyotype, $C$ -

Введение. В селекции мягкой пшеницы на устойчивость к полеганию основным направлением работы является использование генов короткостебельности. У Triticum aestivum L. идентифицировано более 20 генов, оказывающих влияние на формирование высоты растения [1], из них в селекции широко используются гены Rht-B1, Rht-D1 и Rht8. Для этих локусов выявлены серии множественных аллелей, контролирующих разную степень снижения высоты растения [2-5]. Поскольку гены короткостебельности и их аллели различаются по силе воздействия на развитие растения и влиянию на формирование хозяйственно-ценных признаков, целесообразно проведение узконаправленной селекции сортов и подбор наиболее пригодных для конкретных условий культивирования $R h t$-генов и генотипов.

В статье представлены результаты кариотипирования сортов и селекционных образцов озимой мягкой пшеницы и ДНК-типирования у них генов короткостебельности в связи с селекцией на устойчивость к полеганию в Республике Беларусь.

Материалы и методы исследования. Материалом для исследования послужила коллекция из 16 сортов разного экологического происхождения (Капылянка, Влади, Ода, Канвеер, КВС Малибу, Балитус, Тобак, Проспер, Кубус, Фамулус, Балатон, Побак, Августина, Гирлянда, Этюд, Александр) и 16 селекционных образцов озимой мягкой пшеницы, отобранных в НПЦ НАН Беларуси по земледелию по результатам полевых оценок перезимовки, устойчивости к болезням и урожайности. Для определения геномной структуры экспериментального материала был использован метод дифференциального окрашивания хромосом по Гимза (С-бэндинг) [6]. Выявление аллельного состояния генов короткостебельности Rht-Bl, Rht-D1 и Rht8 проводилось с использованием праймеров в модификации Zhang X. et al. [7].

Результаты исследований. Принимая во внимание тот факт, что в 
селекции пшеницы широко используется отдаленная гибридизация, для эффективного планирования селекционной работы большое значение имеет точная информация о хромосомном составе образцов. В ходе исследования установлено, что большинство образцов (21 из 32 образцов) рабочей коллекции озимой пшеницы характеризуются геномной структурой AABBDD $(2 \mathrm{n}=42)$ без структурных перестроек и замещений хромосом. Сорта озимой пшеницы Влади, Августина, Гирлянда и Этюд, а также селекционные образцы ПСИ 17-6 и ПСИ 18-35 содержат в кариотипе в дисомном состоянии пшенично-ржаную транслокацию 1RS.1BL. Образцы ПСИ 17-11, ПСИ 17-26 и сорта КВС Малибу и Проспер несут в дисомном состоянии делецию 5BS.5BL-del. Селекционный образец 084-40/4-11 является неоднородным по хромосомному составу и содержит растения как без хромосомных перестроек, так и с хромосомной аберрацией 5BS.5BL-del. в моносомном состоянии.

Анализ коллекции по аллельному составу гена $R h t-B 1$ показал, что 6 образцов (Александр, Побак, Тобак, КВС Малибу, ПСИ 17-6, ТИТ-18) содержат в гомозиготном состоянии мутантный аллель $R h t-B 1 b$, обуславливающий снижение высоты растения. Остальные образцы являются гомозиготными по дикому аллелю Rht-Bla. Для гена Rht-Dlвыявлено 2 аллеля - $a$ и $b$, при этом мутантный аллель короткостебельностиR $h t-D l b$ присутствовал в генотипе 8-ми проанализированных образцов пшеницы (Ода, Канвеер, Проспеер, Кубус, ПСИ 17-26, ПСИ 18-32, ЭтW1, ПСИ 18-22). Для изучения аллельного состояния гена $R h t 8$ был использовансцепленный с ним микросателлитный локус $X g w m 261$. В ходе фрагментного анализа полученных продуктов ПЦР было установлено, что в исследованном селекционном материале присутствуют пять типов аллелей локуса Xgwm261- 164 п.н., 174 п.н., 190 п.н., 192 п.н., 196 п.н. Аллель Rht8a (фрагмент 164 п.н.), способствующий увеличению высоты растений на 3-4 см, обнаружен у 6 селекционных образцов. Аллель $R h t 8 b$ (174 п.н.), не оказывающий влияния на целевой показатель, выявлен у большинства исследованных образцов (у 23 из 32 образцов). Коммерчески значимый аллель $R h t 8 c$ (192 п.н.), также как аллель $R h t 8 j$ (196 п.н.), присутствовал у 2-х образцов.

В ходе анализа не выявлено селекционных образцов с комбинациями в генотипе нескольких коммерчески значимых аллелей короткостебельности. В проанализированном селекционном материале с наибольшей частотой $(37,5 \%)$ встречался генотип с комбинацией аллелей Rht-Bla, Rht-Dla и $R h t 8 b$. В 18,8 \% случаев присутствовал генотип Rht-Blb, Rht-Dla, Rht8b, с одинаковой частотой 9,4 \% встречались генотипы Rht-Bla, Rht-Dla, Rht8a / Rht-Bla, Rht-D1b, Rht8a / Rht-Bla, Rht-D1b, Rht8b. Генотипы Rht-Bla, Rht$D l a, R h t 8 c$ и Rht-Bla, Rht-Dlb, Rht8j выявлены у 6,3\% образцов. Преобладание в селекционном материале образцов с аллелями Rht8b и Rht8a может быть связано с влиянием аллельного состава гена $R h t 8$ не только на высоту 
растений, но и на их морозо- и зимостойкость [8]. Поскольку основным критерием при формировании рабочей коллекции сортов и селекционных образцов озимой пшеницы являлась хорошая перезимовка, а специфика погодных условий года способствовала проведению «жесткого» отбора образцов, то растения с аллелем $R h t 8 c$, характеризующиеся наименьшей устойчивостью к негативным факторам перезимовки, могли не пройти отбор.

Заключение. В ходе проведенного молекулярно-цитогенетического анализа получена точная информация о хромосомном составе включенных в исследование сортов и селекционных образцов озимой мягкой пшеницы, которую необходимо учитывать при анализе эффектов генов короткостебельности на устойчивость к полеганию, а также при разработке схемы гибридизации. В результате молекулярного анализа не выявлено селекционных образцов с комбинациями нескольких коммерчески значимых аллелей короткостебельности в генотипе. Проведенные исследования позволяют предположить, что отбор по уровню перезимовки может способствовать закреплению в селекционном материале аллеля $R h t 8 b$, ассоциированного, повидимому, с лучшей зимостойкостью в условиях Беларуси. Это подтверждает важность целенаправленного подбора наиболее эффективных для региона возделывания сочетаний аллелей короткостебельности.

\section{Список литературь}

1 McIntosh R.A., Yamazaki Y., Dubcovsky J., Rogers J., Morris C., Somers D.J., Appels R. and Devos K.M. Catalogue of Gene Symbols for Wheat. 2012.

2 Peng, J.R. 'Green Revolution' Genes Encode Mutant Gibberellin Response Modulators / J.R. Peng, D.E. Richards, N.M. Hartley, G.P. Murphy, K.M. Devos, J.E. Flintham // Nature. - 1999. - V. 400. - P. 256-261.

3 Divashuk, M.G. Identity of the Rht-11 and Rht-Ble Reduced Plant Height Genes / M.G. Divashuk, A.V. Vasilyev, L.A. Bespalova, G.I. Karlov // Russian Journal of Genetics. -2012. - V. 48(7). - P. 761-763.

4 Korzun, V. Genetic analysis of the dwarfing gene Rht8 in wheat. Part I. Molecular mapping of Rht 8 on the short arm of chromosome 2D of bread wheat (Triticum aestivum L.) / V. Korzun, M. Roder, M. Ganal, A.J. Worland // Theoretical and Applied Genetics. 1998. - V. 96. - P. 1104-1109.

$5 \mathrm{Liu}, \mathrm{Y}$. Allelic variation, sequence determination and microsatellite screening at the XGWM261 locus in Chinese hexaploid wheat (Triticum aestivum) varieties / Y. Liu, D. Liu, H. Zhang, J. Wang, J. Sun, X. Guo, A. Zhang // Euphytica. - 2005. - V. 145. - P. 103112.

6 Badaeva E.D., Badaev N.S., Gill D.S. et all. Intraspecific karyotype divergence in Triticum araraticum (Poaceae) // Plant Syst Evol. 1994. Vol. 192. No 1. P. 117-145.

7 Zhang, X., Yang, S., Zhou, Y.,He, Z., Xia, X. Distribution of the Rht-B1b, Rht-Dl and $R h t 8$ reduced height genes in autumn-sown Chinese wheats detected by molecular markers / X. Zhang [et al.] // Euphytica. - 2006. - Vol. 152, №1. - P. 109-116.

8 Эффекты аллелей гена $R h t 8$ по агрономическим признакам у озимой мягкой пшеницы в условиях степи юга Украины / В.И. Файт [и др.] // Цитология и генетика. - 2007. - T. 41, № 2. - С. 30-36. 